\title{
PROBLEMS AND PROSPECTS OF LOGISTICS IN MARKET OF MEAT AND MEAT PRODUCTS
}

\author{
Ludmyla Berezina, Iulia Samoilyk, Olha Sosnovska \\ Poltava State Agrarian Academy, Ukraine
}

\begin{abstract}
The article reports on the problems and explores the prospects of logistics in the market of meat and meat products. The need of dividing the agriculture into five areas has been justified: production of fixed and working capital for the first and second areas; agriculture; processing enterprises; service; trade and commerce. The interpretation of the category "logistics system in market of meat and meat products" has been improved, which, unlike existing covers eight stages of creating products meat industry: forage production, resourcing, production, processing, preparation, storing, transporting, and trading. Logistics system connects these elements, products, minimizes transaction costs and enhances flexibility, adaptability, management system emergence of subjects of this market segment. The approaches to classification of logistics systems in meat industry have been further developed. The following forms of logistics systems in meat industry have been offered: logistics system of vertically integrated structures; cooperative logistics system; independent logistics system. The model of logistic system on the market of meat and meat products has been elaborated. The principles and levers of the functioning and development of it model have been distinguished.
\end{abstract}

Keywords: logistics, logistic system, agro-industrial complex, market of meat and meat products market, classification of logistics systems

DOI: $10.17512 /$ znpcz.2016.1.03

\section{Introduction}

Agro-industrial complex is a very sophisticated economic system. The efficiency of agro-industrial complex is dependent on the balance of relations between the sectors of this area. The combination of these components should be made on the basis of logistics. It will minimize transaction costs, optimize logistics and information flows. The market of meat and meat products is one of the largest segments of the agricultural market. It significantly differs from the other components of the agro-industrial complex by another technological process, conditions of storage, elasticity of demand. The implementation and development of logistics systems in this area is necessary because these will solve following problems: reduce the costs of contracts and delivery of products; determine the optimal amount of production and sale of meat and meat products; optimize production technology; form a competitive product assortment of finished products.

Logistic system on the market of meat and meat products (meat products logistic system) is segmental subsystem of agro logistic system. It covers eight stages of creating products of meat industry: forage production, resourcing, production, processing, preparation, storing, transporting, and trading. Logistics 
system connects these elements, provides optimization of material and information flows among the chain links of the meat products, minimizes transaction costs and enhances flexibility, adaptability, management system emergence of subjects of this market segment.

\section{The review of recent research and publications}

The formation of logistics systems in agriculture has lately attracted the attention of a number of scientists, particularly interesting is the study of A. Wieliczko, A. Hadzhynskyj. I. Kravchuk, A. Kalchenko, E. Krykavsky, S. Moroz, M. Oklander, Y. Ponomareva, O. Bag, E. Skakalina, N. Chukhrai and others. The scientists indicate at a number of problems in the development of logistics systems in agriculture and, particularly, in the meat industry. It determines the relevance of research topic.

\section{A Purpose of the research}

The objective of the article is to improve the interpretation of the category "logistics system in the market of meat and meat products", develop the approaches to structuring the agricultural sector in areas, the classification of logistics systems in the meat industry, and build a model of logistics system on the market of meat and meat production.

\section{Rendering of the main results of research}

The inter-economic relations are the main factors of developing logistics in market of meat and meat products. According to A. Bunchykov, O. Holodov, E. Bunchykova, "In a market economy it is very important to adapt the basic principles of organizational and economic relations of subjects of agriculture. All their activities should be based on mutual interest, partnership. Thus, the importance belongs to economic relations, as the incomes are distributed through this mechanism among all participants of the food market" (Бунчиков, Холодов, Бунчикова, 2009, pp. 79-83).

Classical scholars of economics subdivide agriculture in to three areas. The first area is the production of fixed and working capital for the second and third areas of agriculture. The second sector is agriculture. The third sector is processing and service enterprises. However, the development of market relations requires more detailed structuring of agriculture.

For example, some authors identify the fourth area of agro-industrial complex servicing enterprises in agriculture. Makin $\mathrm{H}$. justified the need for the fifth area the area of circulation sector (wholesale and retail trade, procurement of products) (Макин 1998, p.214).

We support the views of scientists on expediency of changing approaches to structuring the agricultural sector and consider it appropriate to of service as distinguish agro-industrial the fourth area. This area includes the transportation companies, organizations of warehousing and storage, repair crews. 
The fifth area should include trade and marketing companies. Herewith, logistics management should comprise all the five levels of relationships (figure 1).

Thus, in agriculture the implementation of logistics systems should be considered in terms of their integration into the management system, as well as a mechanism for modernization of the infrastructure of the economic system.

\begin{tabular}{|l|}
\hline $\begin{array}{l}\text { The first sphere: production } \\
\text { of fixed and working capital } \\
\text { for the second and third areas } \\
\text { of agriculture. }\end{array}$ \\
\cline { 2 - 3 }
\end{tabular} \mid $\begin{gathered}\text { Optimization of needs and supplies of feed, } \\
\text { mtans bud of animals protection, vaccines; } \\
\text { fodder production, production of fodder } \\
\text { crushing and mixing machines, the rational } \\
\text { placing of animals in fattening complexes }\end{gathered}$

\begin{tabular}{|l|l|}
\hline $\begin{array}{l}\text { The second sphere: } \\
\text { agriculture } \\
\text { enterprises }\end{array}$ The fourth sphere: agrarian \\
servicing \\
commercial organizations
\end{tabular}

Figure 1. Model of logistic management system of relations in the market of meat and meat products

Source: Developed by the author.

Logistics in agriculture encompasses several operational stages: preparation of raw materials, production, processing, marketing, distribution, warehousing of finished products. According with it there are should be distinguished procurement, production and the food, distribution, transport and marketing. Types of logistics and construction areas of logistics systems are based on the development and specialization of agricultural enterprises. Thus, the market of meat and meat products is providing such specific types of logistics: feed production, fattening, examination, veterinary, production and processing. Therefore, it is appropriate to consider the classification of logistics and identify specific classification features in the meat industry. 
The formation and classification of logistics systems in agriculture has recently attracted the attention of a number of scientists, particularly interesting is the study of A. Wieliczka, A. Hadzhynskoho, I. Kravchuk, A. Kalchenko, E. Krykavsky, S. Moroz, M. Oklander, Y. Ponomareva, O. Bag, E. Skakalinoyi, N. Chukhrai and others.

Summarizing the views of scientists on classification of agrologistics systems, it should be noted that the mechanism of their formation differs significantly depending on the type, size and legal form of market entities.

The study of A. Sumets is substantial in logistics. He analyses quite thoroughly the approaches to systematization and classification of logistical activity of agricultural enterprises and the distinguishes its types: localization of production and storage, purchasing the necessary material and technical resources to ensure the enterprise is functioning, delivery of spare parts, transportation and movement of material and technical resources their warehousing and inventory management, materials handling, processing and packaging of products, monitoring the movement of agricultural products, forming and maintaining relationships with suppliers, intermediaries and consumers, distribution and customer service in specific market segments (Сумець 2014, pp. 157-163; Brzozowska, Kalinichenko, Kabus, 2015, pp. 10-14).

The scientist identifies 19 types of logistics activities as a result of systematization and generalization. These type are carried out within the logistics system of production and processing of agricultural enterprises. The scientist identifies functional and phase logistics systems. Functional logistics includes operational processes such as procurement, movement and transportation, inventory management, customer service, handling, delivery of spare parts, monitoring the movement, storage, communications, packaging, staffing, the location of production and warehouses. Phase logistics is formed depending on the stage of production of goods (works, services) of financial and information flows, sourcing, manufacturing, distribution and marketing, return, recycling, destruction.

Scientific approaches to the classification of logistics, including agro-industrial, are very common, that once again underlines the appropriateness to identify specific classifications based on industry and specialization of production activity of the agricultural enterprises (table 1).

We are to highlight specific features in the meat industry on the basis of summarizing the classification approaches in agro logistics. One of these signs is the legal form of elements interaction of the economic system. According to this feature independent logistics can be selected, emerging in companies that do not belong to any associations agroformations; logistics of vertically integrated structures which is particularly characteristic of agricultural holdings, which have vertical supply-product chain; cooperative logistics (it is formed on the basis of agricultural service cooperatives, which may include different size and organizational legal forms of entities and households).

It is expedient is distinguishing basic logistics by the character of business processes (this type of logistics includes the production of finished products and is subdivided in to faltering, production and processing, distribution) and auxiliary- 
serving (formed within the auxiliary and service processes that accompany and promote the production of the main products: feed production, examenation, veterinary and ecological). Two types of logistics should be considered in management area: infrastructural logistic that promotes the formation of production and auxiliary facilities serving economic system; and marketing and management, which involves the integration of management functions in the management of information and material flows to ensure the marketing orientation of production.

Table 1. General classification system of logistics in the meat industry

\begin{tabular}{|c|c|c|}
\hline $\begin{array}{c}\text { Classification } \\
\text { feature }\end{array}$ & $\begin{array}{l}\text { Type of } \\
\text { logistics }\end{array}$ & Characteristics \\
\hline \multirow{4}{*}{$\begin{array}{l}\text { According to } \\
\text { the level of } \\
\text { formation }\end{array}$} & Micrologistics & Formation of logistics systems within the enterprise \\
\hline & Mezologistics & Formation of logistics systems within the region \\
\hline & Macrologistics & Formation of logistics systems within the state \\
\hline & Megalogistics & Formation of logistic systems international on the level \\
\hline \multirow{2}{*}{$\begin{array}{l}\text { According to } \\
\text { environment } \\
\text { implementation }\end{array}$} & Internal & $\begin{array}{l}\text { Combines one economic system (enterprise, legally } \\
\text { incorporated group of companies) }\end{array}$ \\
\hline & External & Combines several economic systems \\
\hline \multirow[t]{2}{*}{$\begin{array}{l}\text { According to } \\
\text { functional basis }\end{array}$} & Operating & $\begin{array}{l}\text { Covers production and nonproduction processes } \\
\text { (purchase, movement and transportation, choice of } \\
\text { technology, primary production, processing, sales of } \\
\text { finished products, inventory management, service } \\
\text { organization, loading, unloading, delivery of spare parts, } \\
\text { warehousing, communications forming, packaging) }\end{array}$ \\
\hline & Stage-by-stage & $\begin{array}{l}\text { Combine stage of production, work, services (contracting, } \\
\text { procurement, production, processing, distribution, sales, } \\
\text { return, formation supplies) }\end{array}$ \\
\hline \multirow{2}{*}{$\begin{array}{l}\text { According to } \\
\text { the level of } \\
\text { coverage }\end{array}$} & General & $\begin{array}{l}\text { Covers all the processes and stages and operations of the } \\
\text { economic system }\end{array}$ \\
\hline & Local & $\begin{array}{l}\text { Covers the part of processes operations stages of the } \\
\text { economic system }\end{array}$ \\
\hline \multirow{2}{*}{$\begin{array}{l}\text { According to } \\
\text { form of } \\
\text { realization }\end{array}$} & Own & $\begin{array}{l}\text { Implementation through services one is own economic } \\
\text { resources }\end{array}$ \\
\hline & Outsourcing & Envisages attraction of external logistics \\
\hline
\end{tabular}

Source: Developed by the author.

Thus, the formation and development of logistics systems in the meat sector of agricultural enterprises is a complex process that requires sophisticated mechanisms. According to this, different types of logistics can be used in this industry in obedience to the following general classifications: the level of formation, the environment of implementation, functional basis, the level of coverage, the form of implementation. It is helpful to distinguish specific features (according to the legal form of interaction between the elements of the economic system, the nature of business processes, management area). These types of logistics determine the mechanism of construction and operation of the logistics system for this market segment. 
It should be noted the mechanism of building logistics systems differs significantly depending on the type, size and legal form of market entities.

It is worth paying attention to the views of A. Wieliczko. He differentiates corporate and cooperative logistics in agribusiness and notes that corporate agro logistics is a logistics, in which the successive stages of the supply, production and distribution are within one or several person control to maximize corporate financial results. Cooperative agro-logistics is a logistics, in which the successive stages of the supply, production and distribution are controlled through democratic governance and many persons equal co-ownership, mainly on nonprofit basis, in order to minimize logistics costs of the owners (members) (Величко 2012, pp. 233-238).

The current state of the agricultural market is accompanied by a dynamic development of agricultural service cooperatives, in this regard in recent years there has been a significant number of works devoted to the development of this form of associations of enterprises, and, in particular, agro-logistics building systems on a cooperative basis. These questions have been studied by V. Andriychuk, V. Zinovchuk, A. Krysalnyj, M. Kisil, T. Kosarev, I. Kravchuk, P. Makarenko, M. Malik, G. Pidlisetskyj, P. Sabluk, V. Yurchyshyn and others.

Kravchuk I. notes that service cooperatives in the agri-food logistics are the subjects of integration between producers of agricultural raw materials, processing enterprises, other members of the agricultural market. Their activities are aimed at optimizing the supply chain of agricultural products, which helps to reduce transaction costs and economic risks of suppliers, improves the incomes of agricultural producers makes impossible "dictating terms" by the processing unit to producer-seller (Кравчук 2014, pp. 132-136).

The constructing of agro-logistics systems in vertically integrated structures has significant peculiarities. Skakalina E. notes that integration in the field of agribusiness is economically feasible process that can reduce transaction costs, ensure a steady supply of resources and marketing products. However, the factor of reducing transaction costs is offset in vertically structured corporations by the need to maintain the structure of vertical integration elements with low or negative profitability. The implementation of the benefits of integration is possible only in corporations with a rational shaping of their organizational and production structure that takes into account both the technological features of production and external conditions. The integration of information flows is of great importance in the process of optimizing logistics processes. The integration of the necessary information flows (forecasts, orders, marketing plans, reports on the status of orders and sent cargo) that circulates within the agricultural holding and between partners in the distribution channel, significantly improves the efficiency of inventory using and business as a whole, and helps to reduce uncertainty (Скакалина 2014, pp. 106-108).

Thus, the formation of logistics systems in agriculture is complex and can take many forms depending on the organizational and legal status. This issue is covered in a significant number of scientific papers, which address differences and features of logistics systems for agricultural enterprises different size and legal form. 
However, in modern of literature there are only a few works which are devoted to the fundamental and applied basis of the sectoral features of systems livestock farming, in particular agro-logistics.

The approach to building an integrated logistics system on a corporate basis is a new one in the scientific literature. These logistics system is the most characteristic of agricultural holdings, and cooperative basis, which is a characteristic manifestation of agricultural service cooperatives.

Both corporate and cooperative forms of agribusiness play an important role in the control of the logistics value chain of products and protect economic interests (Величко 2012, pp. 233-238).

The logistics division into internal and external is the most common.

Cooperative or corporate business organizations are subjects of internal logistics in system of cooperative and corporate agribusiness. They independently form such external processes as procurement, storage, sale, transportation, etc., the subjects of logistics are specialized cooperative or corporate enterprises (logistics operators) than ensure the implementation of part or the complex of flow processes of separate cooperative or corporate organization). Internal logistics provides service of exclusively its own flow processes (closed or limited logistics), and in conjunction with this, the additional use of logistics facilities on the side (insorsing). Agro logistics insorsing in agricultural service cooperatives involves the use of logistic capacities to provide services to both its members and other customers. Agro logistics subcontracting of in agricultural service cooperatives is the traditional service connected with transportation and storage with insignificant integration with the serviced customer ( Величко 2012, pp. 233-238).

Kravchuk I. proposes to consider private and corporate and farm-cooperative logistics. The scientist noted that "private and corporate and farm-cooperative forms of agricultural enterprise hip are promising in the development of agro logistics in Ukraine, where agricultural service cooperatives are the main local agents. Regional integration of agricultural service cooperatives, processors, retailers (supermarkets), and other subjects of the food market is effective factor of agro-logistics. The possibility from formation of analytical and information support of members of cooperatives, professional implementation of business planning, legal assistance, capacity for vertical integration with various corporate entities within and outside the region are advantages of regional cooperative centers" (Кравчук 2014, pp. 132-136).

Thus, the following forms of logistic systems should be distinguished in meat industry: logistic system of vertically integrated structures; cooperative logistics system; independent logistics system.

This division of logistics systems is associated with the form of the loss of the legal independence of market entities. There are enterprises that fully or partially, formally or informally, lose their freedom to make management decisions and change their legal form. In particular, vertical or horizontal integration of enterprises in the establishing agricultural holdings, concerns, conglomerate mongering of companies because such structures are dominated by internal logistic system, as most market transactions are replaced by internal farm. 
The market of meat and meat products in modern conditions is characterized mostly by functioning independent producers and agricultural holdings, is this market segment is dominated by vertically integrated logistic structures and independent logistics. The cooperative movement in the meat industry is at the stage of development, there more created milk cooperatives since the industry has a higher level of competitiveness and the cooperation of manufacturers of these products is easier, compared to meat branch.

The mechanism of formation and development of logistics systems in meat and meat products agricultural enterprises should be based on the following levers of economic management: coverage of all parts of the food supply-chain; automation and computerization of logistics flows; target-oriented approach; alternative in building logistics systems.

Local logistics systems can also exist within the overall economic system. They unite the individual stages or operations with livestock production, such as forage production and feeding. However, these local systems have to be integrated into the overall logistics system to facilitate obtaining synergies and forming an efficient logistics infrastructure.

The mechanism of logistics systems in meat and meat products market will be effective subject to the implementation of modern computer technology, navigation, automated systems for controlling, ensuring the optimization of operations and processes at all stages of production and minimize the loss of materials and information. The creation of effective transport systems is very important in meat industry. These transport systems are save resources, contribute to the preservation of qualitative properties of meat products. It will be positively displayed on its realization value.

Management decisions in logistics systems must be based on linking objectives with the resources. It is necessary to develop complex interrelated logistics projects, covering all the processes and transactions in the chain "supplyproduction-processing-storage- trading".

The main principles of formation of logistics systems in the meat industry are: flexibility and adaptability of the logistics system; consideration of integration and cooperative mechanisms in this market segment; coordination of all elements of the logistics system; structuring logistics subsystems depending on the market environment (micro, meso, macro, global level); reflect the specificities of meat products; the use of innovative approaches. These principles should be observed collectively and complementary logistic mechanism of the meat products logistics.

The efficiency of the logistics system may be achieved by provided agricultural cooperation of economic structures, including agricultural enterprises, farms and households, combined in agricultural service cooperatives, and local communities (figure 2).

The construction of agro-logistics systems based on agricultural holdings is effective, but it may prove uncompetitive in the long run because the main purpose of the large vertical structures is profit maximization at the moment. 




Figure 2. The model of the logistic system in market of meat and meat products

Source: Developed by the author.

\section{Conclusions}

In order for the market of meat and meat products to be efficient, the development of agro logistics systems is crucial. The use of logistics in meat industry is an integrative part of agricultural farm management and an important element of economic subject infrastructure. The main factors of economic management and logistics systems development in meat industry are: all parts of 
food supply-chain, leveraging information technology for logistics, target-oriented approach. There are following leading organizational and legal forms of logistics systems: internal logistics systems of larger independent companies or enterprises, multifunctional agricultural cooperative, specialized logistics agricultural service cooperatives, logistics (or marketing and logistics association), a subdivision of advisory service, the contractual relationship agro-logistics with independent outscoring logistics company.

\section{References}

[1] Brzozowska A., Kalinichenko A., Kabus J., Analyzing the strategies used in media discourse management, J. Eastern-European Journal of Enterprise Technologies, Vol 5, No 3(77) (2015), pp. 10-14. DOI: http://dx.doi.org/10.15587/1729-4061.2015.51397

[2] Бунчиков О.Н., Холодов О.А., Бунчикова Е.В., Сущность и особенности экономических отношений в АПК / // Вестник аграрной науки Дона. - 2009. - № 1, pp. 79-83.

[3] Величко О.П., Корпоративна і кооперативна логістика в агробізнесі // Вісник Хмельницького національного університету - 2012. - № 1, pp. 233-238.

[4] Кравчук I.А., Роль обслуговуючих кооперативів в агропродовольчій логістиці // Кооперативні читання: 2014: матеріали Всеукр. наук.-практ. конф., 27-29 берез. 2014 p. - Житомир: ЖНАЕУ, 2014, pp. 132-136.

[5] Макин Г.И., Система управления агропромылиленным комплексом в переходный период. - М.: АгриПресс, 1998, р.214.

[6] Скакалина Е.В., Структура логистической компоненты ERP-системы агрохолдинга // Вестник Полтавской государственной аграрной академии. - 2014. - № 1, pp. 106-108.

[7] Сумець О.М., Систематизачія видів логістичної діяльності підприємств агропромислового комплексу // Економічний форум. - 2014. - № 2, pp. 157-163.

\section{PROBLEMY I PERSPERTYWY LOGISTYKI NA RYNKU MIĘSA I PRODUKTÓW MIĘSNYCH}

Streszczenie. Uzasadniono konieczność podziału rolnictwa na pięć sfer: wytwarzanie kapitału trwałego i obrotowego dla pierwszej i drugiej sfery; rolnictwo, przedsiębiorstwa przetwórcze; sfera obsługi oraz handel. Zaprezentowano ulepszoną interpretację kategorii "system logistyczny na rynku mięsa i produktów mięsnych", która, w przeciwieństwie do poprzednich, obejmuje osiem etapów tworzenia produktów przemysłu mięsnego: produkcja paszy, zapewnianie niezbędnych środków, produkcja, przetwarzanie, przygotowanie, przechowywanie, transportowanie oraz handel. System logistyczny łączy te elementy, zapewnia optymalizację przepływu materiałów i informacji pomiędzy ogniwami łańcucha produktów mięsnych, minimalizuje koszty transakcji i zwiększa elastyczność, zdolność przystosowania się. W dalszej części rozwinięto podejścia do klasyfikacji systemów logistycznych w przemyśle mięsnym. Zaproponowano następujące formy systemów logistycznych w przemyśle mięsnym: system logistyczny struktur zintegrowanych pionowo, wspólny system logistyczny, niezależny system logistyczny. Szczegółowo omówiono model systemu logistycznego na rynku mięsnym i produktów mięsnych. Zidentyfikowano zasady i instrumenty funkcjonowania tego modelu.

Slowa kluczowe: logistyka, system logistyczny, kompleks rolno-przemysłowy, rynek mięsa i produktów mięsnych, klasyfikacja systemów logistycznych 